\title{
СТОРІНКА РЕЦЕНЗЕНТА
}

\section{АГРАРНІ ТРАНСФОРМАЦІЇ ПЕРІОДУ УКРАЇНСЬКОЇ РЕВОЛЮЦІЇ 1917-1921 pp.}

Рецензія на монографію: Корновенко С.В., Земзюліна Н.І., Ковальова Н.А., Малиновський Б.В., Масненко В.В., Морозов А.Г., Михайлюк О.В., Пасічна Ю.Г. Селянство, земля і влада в період Української революції (1917-1921 рр.). Черкаси, 2020. 440 с.

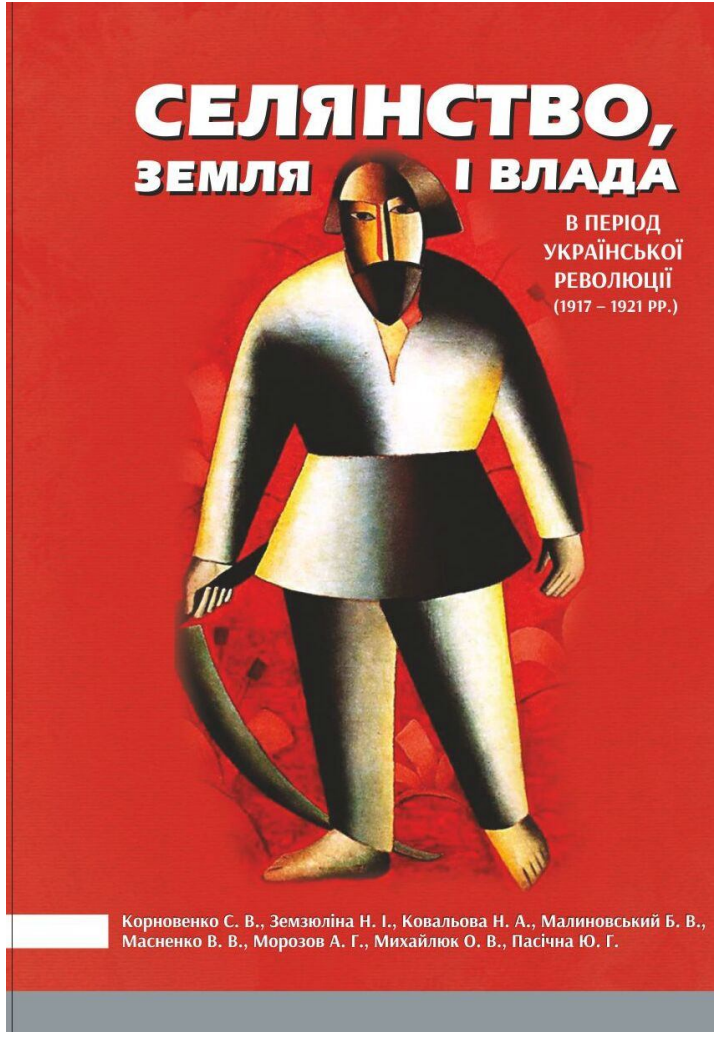

Події Української революції 19171921 рр. докорінно вплинули на суспільнополітичну ситуацію в Україні. Процеси, що зародилися в умовах Першої світової війни, позначилися на всіх сферах життя суспільства. Одним із рушіїв Української революції цілком обгрунтовано, на нашу думку, вважають селянство, адже аграрний складник був найвиразніший у подіях Української революції. Сьогодні актуальним вважаємо ознайомлення громадськості 3 подіями Української революції 1917-1921 pр. як одним із визначних етапів розбудови української державності.

Монографія «Селянство, земля і влада в період Української революції (19171921 pр.)» є вдалою спробою пояснення тогочасних соціокультурних трансформацій, змін аграрного законодавства, аналізу проведення перетворень у сфері землеволодіння та землекористування різними

\footnotetext{
* Священко Зінаїда Василівна - доктор історичних наук, професор кафедри всесвітньої історії та методик навчання Уманського державного педагогічного університету імені Павла Тичини (Умань, Черкаська область, Україна); ORCID: http://orcid.org/0000-0001-5845-3115; e-mail: szv09@meta.ua
} 
політичними режимами в українському селі періоду Української революції 1917-1921 рр. широкому загалу.

Iз застосуванням загальнонаукових і спеціальних методів історичного пізнання авторський колектив довів важливість аграрних перетворень протягом 1917-1921рр. в Україні. Позитивним вважаємо залучення до монографії значного масиву раніше неопублікованих джерел, що розміщені у сховищах Центрального державного архіву вищих органів влади і управління України, Центрального державного історичного архіву (м. Київ), Державного архіву Миколаївської області, Державного архіву Автономної Республіки Крим, Державного архіву Російської Федерації, Російського державного військового архіву тощо.

Структурно монографія поділяється на декілька розділів, що взаємодоповнюють один одного та дозволяють максимально комплексно проаналізувати аграрну ситуацію та аграрні трансформації в період Української революції 1917-1921 рр.

у монографії проаналізовано соціокультурні трансформації в українському селі, вивчено аграрну політику Тимчасового уряду, зміни агарного законодавства Центральної Ради, досліджено зміст аграрного законодавства Гетьманату, напрями аграрної політики Директорії УНР, описано особливості аграрної політики Австро-Угорщини та Німеччини, проаналізовано аграрну політику Білого руху Півдня Росії, у завершальному розділі досліджено аграрну політику радянської влади.

Вважаємо, що монографія має суспільно-практичне значення та буде корисною для студентів закладів вищої освіти та науковців під час вивчення подій Української революції 1917-1921 рр. Виконання монографії згідно з держбюджетною темою «Українська революція (1917-1921 рр.): селянський фактор» (номер державної реєстрації 0118U003864) дозволяє констатувати про системний підхід до дослідження.

Підбиваючи підсумки, зазначимо, що рецензовану монографію вважаємо завершеним комплексним дослідженням, яке грунтовно доповнює історичні знання щодо аграрної історії періоду Української революції 1917-1921 pp. Авторські висновки вдало підтверджуються розміщеними у кінці кожного розділу документами та матеріалами 3 теми дослідження. Рецензована монографія «Селянство, земля і влада в період Української революції (1917-1921 рр.)» є значним здобутком сучасної української аграрної історіографії, адже беззаперечно доводить значущість аграрних змін для українського суспільства протягом 1917-1921 рр. 